\title{
RESEARCH
}

\section{PERCEPTIONS AND EXPERIENCES OF OLDER PEOPLE REGARDING THE COVID-19 PANDEMIC PROCESS: A PHENOMENOLOGICAL STUDY}

Turkish Journal of Geriatrics

DOI: $10.31086 /$ tigeri.2021.252

2021; 24(4): 546-556

- Yeliz AKKUŞ ${ }^{1}$

- Ayşe Gül PARLAK ${ }^{2}$

- Yasemin KARACAN ${ }^{3}$

- Gülnaz KARATAY ${ }^{4}$

\section{CORRESPONDANCE}

\section{${ }^{1}$ Yeliz AKKUŞ}

Kaikas University, Health Science Faculty Nursing Department, Kars, Turkey

Phone: +904742251567

e-mail: yelizakkus@gmail.com

Received: Nov 13, 2021

Accepted: Nov 29, 2021

${ }^{1}$ Kaikas University, Health Science Faculty Nursing Department, Kars, Turkey

${ }^{2}$ Kafkas University, Vocational Health School, Kars, Turkey

${ }^{3}$ Uludağ University, Health Science Faculty Nursing Department, Bursa, Turkey

${ }^{4}$ Munzur University, Health Science Faculty Nursing Department, Tunceli, Turkey

\section{Abstract}

Introduction: From the start of the coronavirus disease 2019 (COVID-19) outbreak in 2020 to the present, older people have been the worst affected among all age groups. This study was conducted to examine thoroughly the perceptions and experiences of older people regarding the COVID-19 outbreak.

Materials and Methods: A qualitative study was conducted using a semistructured, in-depth interview method with 16 older people living in the east of Turkey. The interviews were conducted through the mobile application WhatsApp, as the older people were in the risk group for infection. The sample group was reached using the snowball method. When the data obtained from the participants reached the saturation level, two more interviews were conducted, and then the interviews were ended. After the recorded interviews were transcribed, they were subjected to conventional content analysis.

Results: Four main themes emerged from the interviews in line with the purpose of this study. These themes are The Meaning of COVID-19, Outcomes of COVID-19, Need for Support and Resources, and Attitudes toward Vaccination.

Conclusion: It was determined that the older people experienced fear during the COVID-19 pandemic; the social restrictions affected them psychologically, physiologically, and economically and they could not get enough support and felt lonely in this process; but nevertheless, they were hopeful about the vaccine. To address these findings, this study suggested support for home care of older people and the development of psychosocial and economic support programs for them.

Keywords: Geriatrics; COVID-19; Pandemics; Mental Health. 


\section{INTRODUCTION}

Degenerative changes in the immune system, too much inflammation, cytokine storm, epigenetic changes that occur with aging, and comorbidities put older people at risk of acquiring and dying from COVID-19(1). The World Health Organization $(\mathrm{WHO})$ issued a statement that "Older people are at the highest risk from COVID-19". In Turkey, the first measure taken to prevent the spread of the virus was the announcement on March 21, 2020 of a curfew for people older than 65 and for those with chronic diseases. Due to the implementation of the curfew, the older people were confined to their homes and so had to stop all their usual out-ofhome physical, social, and economic activities, even with their own family members who were not living with them (2).

Along with social isolation and strict quarantine measures, the confinement of older people to their homes has been the most effective method of preventing the spread of COVID-19. However, the quarantine measures and travel restrictions during the COVID-19 pandemic have caused physical and mental problems among older people because they are not allowed to walk outside, including in parks; have face-to-face social interactions, including with their family members and other loved ones; and have contact with animals and plants, besides which they find it difficult to access medicines and hospitals(3). The physical problems that have been identified include undereating or irregular eating habits, immobility and a resulting increase in pulmonary and cardiovascular problems, and osteosarcopenic obesity, which negatively affects respiratory muscles and function (4) and has been predicted to cause an increase in cases of acute respiratory distress syndrome due to COVID-19 and of mortality and morbidity due to pneumonia(5). The most common mental problems can be listed as fear of infection and death, concerns about relatives, depression or anxiety such as due to lack of information or financial inadequacy, and fear of stigmatization due to their high potential to spread the virus $(6,7)$. Indeed, the higher COVID-19 mortality rate among older people and the frequent emphasis of this fact in the media have caused intense fear in this age group(8).

The disproportionate effects of COVID-19 on older people and the implementation of restrictions and prohibitions predominantly on older people have had serious negative effects on the elderly population. It is important to reveal these negative effects especially on older people in different cultural groups. In this paper, we present the COVID-19 pandemic perceptions and experiences of people aged 65 and above in Turkey, where the elderly population accounts for $9.5 \%$ of society and is increasing.

\section{MATERIALS AND METHODS}

\section{Study Design}

This study was designed as a qualitative study using interviews and content analysis. Colaizzi's phenomenological approach was used to discover the older people have lived experiences and perceptions of the COVID-19 pandemic.

\section{Setting and Sampling}

Individuals aged 65 and above who are living in a community in a province in the east of Turkey were included in this study. The older people were reached with the snowball sampling method guided by purposeful sampling. The inclusion criteria were individuals who were over 65 years of age, who did not have a mental or cognitive disorder or impairment, who could express themselves well verbally, and whose participation in the study was voluntary. Thus, the study was completed with a total of 16 people, 6 of whom were male and 10, female. 
Table 1. Semi-structured Interview Form

1. What does COVID-19 mean to you? Can you explain?

2. What have you experienced (physical, psychological, social, and familial) during the COVID-19 outbreak? Can you explain?

3. In your opinion, what kinds of support (financial, instructional, solidarity support, etc.) do older people need during the pandemic process and to what extent have these been provided? What are your expectations??

4. What aspects of your life have changed from before the pandemic to during the pandemic?

5. Due to the COVID-19 pandemic, a curfew was imposed on people over the age of 65 . What difficulties did you experience during this restriction?

6. What are your thoughts on COVID-19 vaccination?

\section{Data Collection Method and Tools}

The interviews were conducted on the mobile messaging application WhatsApp with face to face between December 15, 2020 and March 15, 2021, starting with the collection of the participants' personal information. Then interviews were conducted using the semi-structured interview form (Table 2) that the researchers developed, which is presented in the next section. The in-depth interview method was used to allow for deeper understand the responses(9). The responses were recorded on a Sony digital voice recorder and were transcribed by ... and....

\section{Data Analysis}

The data obtained from the interviews were documented manually in the Microsoft Word program. To keep the identities of the participants confidential, each participant was coded as Participant 1, Participant 2, P3, P4, P5,.........P16. Then their responses were analyzed using Colaizzi's (1978) seven-step phenomenological data analysis method, as follows $(9,10)$.

\section{Rigour and Trustworthiness}

The precision of the study was maintained following the qualitative study criteria, contrary to the positivist perspective. The two researchers independently examined the documents obtained from the interviews and independently created codes and themes. Then their codes and themes were brought together, and common codes and themes were combined. The data were checked again to ensure no overlapping codes and themes, and to ensure consistency with the interview responses by asking the researcher who conducted the interview and all participants. The themes and findings were evaluated by an external researcher who was not involved in the data collection and evaluation process. This external researcher approved all the themes and findings (9).

\section{Ethical Issues}

This study was conducted in accordance with the principles of the Declaration of Helsinki. Prior to the study, it was approved by the Faculty of Health Sciences Ethics Committee of a university (date: April 12, 2020; approval number: 115), by the Turkish Ministry of Health and participants.

\section{RESULTS}

Four themes emerged from the interview responses: The Meaning of COVID-19, Outcomes of COVID-19, Support and Resources, and Attitudes toward Vaccination (Table 3). The findings are presented as follows according to each of these themes.

\section{The Meaning of COVID-19}

Multifaceted Fear: "It exploded like a bomb and spread everywhere." 
Table 2. General Characteristics of Participants

\begin{tabular}{|c|c|c|}
\hline & $n$ & $\%$ \\
\hline $\begin{aligned} \text { Gender } & \\
& \text { Female }\end{aligned}$ & 10 & 62.50 \\
\hline $\begin{array}{r}\text { Age } \\
65-69 \\
70-74 \\
75-80 \\
\end{array}$ & $\begin{array}{l}6 \\
5 \\
5\end{array}$ & $\begin{array}{l}37.50 \\
31.25 \\
31.25\end{array}$ \\
\hline $\begin{array}{r}\text { Marital Status } \\
\text { Married }\end{array}$ & 10 & 62.50 \\
\hline $\begin{array}{l}\text { Educational Level } \\
\text { Illiterate } \\
\text { Literate-Elementary School } \\
\text { High school } \\
\text { University }\end{array}$ & $\begin{array}{l}6 \\
5 \\
2 \\
3\end{array}$ & $\begin{array}{l}37.50 \\
31.25 \\
12.50 \\
18.75\end{array}$ \\
\hline $\begin{array}{l}\text { Housewife } \\
\text { Retired }\end{array}$ & $\begin{array}{r}10 \\
6\end{array}$ & $\begin{array}{l}68.75 \\
31.25\end{array}$ \\
\hline $\begin{array}{l}\text { People they are living with } \\
\text { Alone } \\
\text { Partner } \\
\text { Partner and children } \\
\text { Children/Grandchildren }\end{array}$ & $\begin{array}{l}1 \\
6 \\
4 \\
5\end{array}$ & $\begin{array}{r}6.25 \\
37.50 \\
25.00 \\
31.25\end{array}$ \\
\hline $\begin{array}{l}\text { How s/he evaluates her/his health compared to her/his peers } \\
\text { Better } \\
\text { Same } \\
\text { Worse }\end{array}$ & $\begin{array}{l}7 \\
7 \\
2\end{array}$ & $\begin{array}{l}43.75 \\
43.75 \\
12.50\end{array}$ \\
\hline $\begin{array}{c}\text { Chronic Illness } \\
\text { Yes }\end{array}$ & 12 & 75.00 \\
\hline Total & 16 & 100.00 \\
\hline
\end{tabular}

Many participants described the COVID-19 infection as a "terrible" and "filthy" disease associated with death. One participant stated that COVID-19 "exploded like a bomb and spread everywhere" (P1, 68, female), but she meant that the onset of the virus was sudden but its impact was tremendous and widespread.

Some of these fears were also linked to the fear of death.

. . . I am depressed; people died. Terrible disease does not give up, it always kills, I am afraid of it. ... (P1, 68, female)

.. reminded me of death. I always lived on my nerves thinking I could get infected . . I couldn't sleep for months. ... (P7, 65, female)

One of the participants experienced fear so intensely that she said, "I never left home for months, I was anxious even if I went out on the balcony, I neither ate nor drank. . . " (P8, 65, female)

One of the participants stated, "We did not know such a thing until today, we could not be cautious at the beginning, " and added that this was the first time in his 66 years of life that he had come across such an epidemic (P15, 66, male).

Social Restriction: "Mother runs away from her child." 
Table 3. Main and Sub-Themes of Participants' Covid-19 Pandemic Experiences

\begin{tabular}{|c|c|c|}
\hline Themes & Subthemes & Exploring \\
\hline \multirow[t]{3}{*}{$\begin{array}{l}\text { The Meaning of Covid-19: } \\
\text { Multifaceted Fear }\end{array}$} & Multifaceted Fear & $\begin{array}{l}\text { 1. Death } \\
\text { 2. Lack of Support } \\
\text { 3. Not Receiving Health Care Services } \\
\text { 4. Worrying Something Will Happen to the } \\
\text { Children/Relatives } \\
\text { 5. Be in need of care }\end{array}$ \\
\hline & Social restriction & $\begin{array}{l}\text { 1. Not being able to see children/relatives } \\
\text { 2. Not being able to meet with neighbors } \\
\text { 3. Not being able to go out } \\
\text { 4. Unable to attend funerals }\end{array}$ \\
\hline & Biology/Fate Dilemma & $\begin{array}{l}\text { 1. A Microbial Disease } \\
\text { 2. Fate }\end{array}$ \\
\hline \multirow[t]{4}{*}{$\begin{array}{l}\text { Outcomes of Covid-19; Overall } \\
\text { Decline in Health and Well-being }\end{array}$} & Physical & $\begin{array}{l}\text { 1. Inability to go to the doctor } \\
\text { 2. Weight Gain / Stop Eating } \\
\text { 3. Decrease in Physical Activity } \\
\text { 4. Affected Lungs } \\
\text { 5.Disrupted Sleep } \\
\text { 6.Skin Problems } \\
\text { 7. Catching Covid-19 }\end{array}$ \\
\hline & $\begin{array}{l}\text { Psychological /Spiritual } \\
\text { Effects }\end{array}$ & $\begin{array}{l}\text { 1. I was psychologically affected } \\
\text { 2. I had a panic attack } \\
\text { 3. I became obsessive } \\
\text { 4. I felt alone/helpless } \\
\text { 5. Increased forgetfulness }\end{array}$ \\
\hline & Social & $\begin{array}{l}\text { 1. Developing Social Phobia } \\
\text { 2. Loss of Freedom } \\
\text { 3. Watching a lot of TV } \\
\text { 4. Staying away from the inner circle }\end{array}$ \\
\hline & Economic & $\begin{array}{l}\text { 1. Problems Regarding Individual Resources } \\
\text { 2. Problems Regarding Social Resources }\end{array}$ \\
\hline $\begin{array}{l}\text { Need of Support and Its Resources; } \\
\text { "We became self-sufficient". }\end{array}$ & $\begin{array}{l}\text { Economic } \\
\text { Health Care } \\
\text { Information } \\
\text { Psychological/Spiritual }\end{array}$ & \\
\hline $\begin{array}{l}\text { Attitudes toward Vaccination: } \\
\text { "Everyone says something different." }\end{array}$ & $\begin{array}{l}\text { Fear of Side Effect } \\
\text { The Vaccine Offers Hope }\end{array}$ & \\
\hline
\end{tabular}

Some participants described the COVID-19 outbreak in terms of social restriction. The inability of their children to come home to them and thus, their inability to hug their children, was one of the dimensions that they said most affected them emotionally. Below are some expressions of the participants who described the outbreak as social restriction.

Mother runs away from her child. (P1, 68, female)

If a person can't tell her sorrow (social), it means it is bad. (P16, 70, female)

Prison is better than this .... (P3, 80, male) 
... We could not visit our deceased and sick loved ones . . . we were very sorry. . . . (P16, 70, female)

\section{Biology/Fate Dilemma}

Some of the participants described the epidemic as a microbial disease, while others stated that it is just fate. The participants who said it is fate explained that it is God's will and is a kind of test or a situation that is beyond our control.

It is an airborne virus disease. ... (P9, 72, female)

It is an act of Allah, there is nothing I can do. . . (P12, 76, female)

If a person sees the pandemic as a microbial condition, it is unlikely that the person will also pray for protection. The tendency to overcome the pandemic with prayer was higher among the women.

... I throw myself upon Allah's mercy. I pray every Friday. May my Lord save us from this terrible disease.... (P11, 76, female)

\section{COVID-19 Outcomes: Overall Decline in Health and Well-being}

This theme is further divided into the subthemes of physical, mental, social, and economic outcomes or effects. However, although these subthemes are reviewed separately here, it is noteworthy that the participants saw their physical, mental, and social problems as triggering each other and thus, as a chain of problems.

\section{Physical Effects}

The participants reported physical health problems such as not being able to go to the doctor due to the pandemic, reduced physical activity, loss of appetite due to weight gain or anxiety/fear, lung infection from wearing masks, sleep problems, and skin problems. The statements of the participants regarding the physical consequences of COVID-19 on them are as follows:

I was afraid and panicked; I could not go to the doctor, I had kidney pain for 4-5 months, my blood pressure went up, I squeezed plenty of lemons and drank it . . . my heart is pounding too fast. . . (P2, 65, female)

\section{Psychological Effects}

While almost all the participants (16 people) stated that they were psychologically affected, some of them reported that they panicked (2 people), developed fear (6 people), developed obsession (2 people), felt lonely and helpless (4 people), and experienced extreme forgetfulness (2 people).

I had trouble finding a mask, I could not go out, we had a lot of psychological problems, there was nobody, we made do with the food that was at home for 15 days. . . I f felt very lonely thinking that if I got sick, the government would look after me like this. (P5, 71, male)

\section{Social Effects}

Some participants stated that they developed a fear of going out during the pandemic, and that they lost their freedom and missed the old days.

You talk to your neighbor, you unburden yourself, you psychologically feel better, you become each other's remedy. (P2, 65, Female)

One of the participants stated that he was angry with the social restrictions imposed on the older people in this process and found it against the principle of equality.

Are we to be blamed because we are over 65? It is against human rights, what's the damage... we are resentful of the treatment of the older people, we are human beings, they forbid us to get in the car. ... (P10, 72, male)

\section{Economic Effects}

Some of the participants stated that they were affected economically. Others were worrying about those who were close to them, and a few were concerned about people who were not close to them. Most of them stated that their needs are being met by their children, and they said this in a way that 
expressed their satisfaction with being taken care of and not being dependent on someone else. Some of them gave indefinite answers such as "We are trying to make ends meet" or "I am retired, pension is not enough. Just fill the blanks. ..." (P9, 72, male).

It severely affected our economy, the mask is 1 Lira (Turkish currency) ... . (P10, 72, male)

\section{Need for Support and Resources: "We be- came self-sufficient."}

This study also seeks to understand the participants' needs for support and how they met these requirements during the pandemic. The participants described their requirements in terms of economic, health care, informational, and emotional and spiritual support.

\section{Need for Economic Support}

As stated earlier, many of the participants said their economic needs are being met by their children. None of the participants said that they are receiving support from sources other than their family members.

One of the participants disclosed that her inner circle was also in need of support:

... my children have always supported me, but there are people who were never asked how they were doing, they had a lot of difficulties, their children did not come, no grocery shopping, they could not go out. . . (P14, 65, female)

Health Care Needs: "You know, you may escape the bear and fall into the lion."

It was inferred that one of the most difficult situations the participants experienced was that their health care needs were not met during the pandemic. One of the participants expressed her fears about getting health care and its consequences as follows:

We didn't test positive for COVID-19, but it was terrifying and stressful, I couldn't go to the doctor because I was anxious. . . I felt like death after constantly taking painkillers. ... (P16, 70, female)

One of the participants stated that she avoided getting health service even in an emergency:

I got sick twice, I could not go to the doctor, my blood pressure went up, I squeezed a lot of lemons and drank it, I couldn't breathe, I opened the door and window, I breathed deeply. ... (P2, 65, female)

\section{Informational Requirements}

Many of the participants did not mention any source of information on the pandemic other than their children and television. While they followed the developments related to the pandemic through the news, some of them stated that the time they spent watching television increased considerably during this period, and this situation worsened their anxiety level.

I hear about people paralyzed on TV. . . . I followed it daily, I would have a racing heart. I was so affected by the news that my husband started turning off the TV. I don't watch it all the time anymore, I just take a brief look at the news ... as I spent less time watching TV, I felt relieved. . . (P8, 65, female)

Psychological/Spiritual Support Requirement

While all the participants stated that they did not receive professional psychological support, they also stated that they did not receive social support other than from their spouse and children. It is noteworthy that a good many of them used self-coping methods in this process. Religious rituals such as salaat and prayer were used by some participants as sources of spiritual support in dealing with the pandemic.

While performing five times of prayers, I pray to God for no harm to our religion and nation and protection from all kinds of trouble. (P13, 76, male)

\section{Attitudes toward Vaccination: "Everyone says something different."}




\section{Fear of Side Effects}

Most of the female participants had negative attitudes toward the vaccines. Their anxiety and fear of the side effects of the vaccine were evident. Their insecurity about the vaccine was based on speculative information that they heard on television or around them.

One of the participants angrily stated that she would not be vaccinated:

... I am old, what if it affects me adversely, some people were dying after receiving their COVID-19 vaccine ... and they said it had a side effect. I will not be vaccinated. . . I I am against vaccination. (P11, 76, female)

\section{The Vaccine Offers Hope}

A quarter of the participants stated that they have no other option than vaccination to get protection. It is especially striking that the participants who decisively wanted to be vaccinated were men.

We look forward to it because it offers hope, hopes cannot be killed, I can't wait to be vaccinated. (P13, 76, male)

\section{DISCUSSION}

Anxiety and fear are the most important problems that emerged during the COVID-19 pandemic and have had significant effects on the mental health of both individuals and society. Various media have been full of reports that COVID-19 is spreading rapidly all over the world that older people are more affected by the virus, that their mortality rate is high, that they die alone in nursing homes in European countries, and that hospitals are unable to keep up. To prevent the spread of the virus in Turkey, curfew restrictions have been implemented for older people. Subsequently, mosques, prayer rooms, and coffeehouses have been closed, older people are not allowed to go out even only to withdraw their pension, and limited participation in funeral ceremonies has been imposed(11). These practices, which have contributed greatly to the fight against the COVID-19 pandemic, have nevertheless had disproportionately greater negative effects on older people over time, including increased social isolation, loneliness, and mental health problems(12). In addition, after the announcement that the COVID-19 mortality rate is high among older people, their level of anxiety has increased(13). Meng Xu et al. (2020) stated that the older people living in Spain are also developing emotional responses such as insecurity and fear, and $37 \%$ of 1,556 older people are experiencing depression and anxiety $(13,14)$. Yıldırım et al. (2021) stated that anxiety predicts depression in older people(6). In this study, the expression of one of the participants that COVID-19 "exploded like a bomb" depicts the shock experienced by older people. Similarly, in the study conducted in Spain, the older people stated that COVID-19 affects not only China but the whole world; and a study conducted in the Philippines, found that people in all age groups were shocked when the pandemic broke out(13). In this study, the older people stated that the day of the apocalypse is approaching, as "Mother runs away from her child."

In this study, it was observed that the perception of the COVID-19 pandemic as fate by the female older people made it easier for them to cope with it. Such belief in fate is generally explained as follows: "God knows what people will do and what events they will experience beforehand." Indeed, some studies on fatalism have found that it can be a positive coping mechanism for a disease or a psychological problem; but the same studies have found that it can also cause disruptive behaviors in maintaining health or preventing diseases $(15,16)$.

\section{Overall Decline in Health and Well-being}

The COVID-19 pandemic has caused a crisis in the health system in Turkey and over the world. In Turkey, volunteers or law enforcement agencies try to meet their needs instead.(11) However, feelings of insecurity and hopelessness in Turkish society, 
including among older people, have still emerged because the number of COVID-19 cases in the country started to be announced only on November 25, 2020. In this study, the participants were satisfied with the services provided, but might have thought that their health system had collapsed due to their uncertainty, the notion that there is no transparency regarding the number of COVID-19 cases, and their inability to have their chronic illnesses controlled or treated.

The group most affected by COVID-19 is that of older people with comorbidities. As seen in this study, the older people could not go to their routine check-ups or had to delay the treatment of their emerging medical problem. Browne et al. (2020) found that older hypertensive patients had lower step counts than before the pandemic and that their sedentary behavior increased and their physical activity decreased, especially on weekends(17). In addition, the fear of death, which emerged with the rapid spread of the virus, increased older people's subconscious tendency to carry out unreliable solutions from what they hear from the media or their inner circle (such as eating raw garlic every day, constantly sipping water, consuming various foods excessively, and cleaning the house constantly with antiseptic products). Obsessive-compulsive behaviors such as constantly checking their body for signs of illness, taking excessive amounts of vitamin/food supplements, or constantly washing their hands have begun to be observed in older people who are quarantined for possible infection(18). In this study, it was observed that the older people started to clean obsessively.

The quarantine measures in Turkey have increased fear and loneliness, especially among older people. They have also increased problems with adaptation to isolation especially among older people with a low education level, who socialize by interacting with each other face to face. In addition, during the pandemic, older people have been increasingly exposed to discrimination, exclusion, and stigmati- zation. One out of every 10 tweets of young people during the pandemic state that the lives of older people are less valuable(19).

\section{Need for Support and Resources: "We be- came self-sufficient."}

The COVID-19 pandemic has disproportionately affected the economic status of older people. Sectors in which older people work have been affected to a far greater extent during the pandemic, which has caused many older people to lose their jobs and income. Poverty has also increased among older divorced women. Moreover, at the onset of the pandemic, older people retired early to reduce the risk of catching the virus, and those of them who wanted to keep working experienced discrimination in the workplace as they were thought to be at high risk of transmitting COVID-19(20).

In Turkey, the poverty rate of the elderly population was $16.4 \%$ in 2019 and $14.2 \%$ in 2020(21). Financial difficulties were especially reported among older people who had to spend their savings on their needs, such as food and beverages and medicine, due to their long-term isolation and quarantine, which they were unprepared for-especially older people who do not have a pension, fixed income, and savings(7).As seen in this study, the older people living alone were more affected during the pandemic. Amidst this scenario, many older people have resorted to traditional medicine to strengthen their immune system and prevent diseases(22).

The most important source of information of older people in 2020, during the pandemic, was television, since older people in Turkey do not use the internet and other communication tools widely. Similarly, in another study conducted in Turkey, it was found that TV and social media were used as sources of information by older people(23). Since the start of the pandemic, the Turkish Minister of Health has been providing the public daily updates on the country's COVID-19 situation on The Tur- 
quoise Table TV program. Making statements about the pandemic process was expected to reduce the anxiety level in the whole community. However, the increase in the number of cases day by day and the inability to control the pandemic despite vaccination have increased people's anxiety level.

Spirituality is known to provide a calming effect and mental relaxation in times of crisis in societies facing pandemics. During the COVID-19 pandemic, however, the need of older people for spiritual support has been ignored(11). In Turkey, places of worship were closed within the scope of restrictions, and many prayers (i.e., salaat, Friday prayers, and iftar-sahur invitations during Ramadan) that bring older people together and enable them to communicate with their peers could not be held(24). In this study, the older people were negatively affected by their inability to go to places of worship.

An unprecedented scale of effective vaccination in short time intervals offers hope of defeating the COVID-19 pandemic. However, public opposition to the vaccines following the COVID-19 outbreak has increased. It has been stated that even before the pandemic, in 2019, the reach of social media accounts that generated antivaccination messages was already 7-8 million people. A survey by the Center for Countering Digital Hate (CCDH)found that in England, one out of every six people is antivaccination; and in Turkey, there are rumors that COVID-19 was produced for biological warfare and

\section{REFERENCES}

1. Mueller AL, McNamara MS, Sinclair DA. Why does COVID-19 disproportionately affect older people? Aging (Albany NY) 2020;12(10):995981.(PMID:32470948).

2. World Health Organization E. Statement - Older people are at highest risk from COVID 19, but all must act to prevent community spread; 2020. [Internet]. Available from: https://www.euro.who. $\mathrm{int} / \mathrm{en} /$ health-topics/health-emergencies/coronavirus-covid-19/statements/statement-older-people-are-at-highest-risk-from-covid-19\%2C-but-all- the vaccine was developed by Bill Gates to implant microchips in people(25). In Turkey, older people were among the first to be vaccinated, but there is no study yet on the vaccination rate of older people or their attitudes toward COVID-19 vaccination. In this study, the older people were indecisive about COVID-19 vaccination but were willing to be vaccinated because they saw it as their hope. Thus, they are not antivaccination.

\section{Limitations}

It was conducted in a city located in the east of Turkey with older people who have a smartphone and can make calls over the internet. However, the even older people could not be interviewed due to hearing and cognitive difficulties.

\section{Conclusion}

To address these findings, further studies may be conducted to increase psychosocial support systems for reducing the anxiety experienced by older people. New ways of ensuring their risk-free socialization during the pandemic may be introduced. Voluntary or economic income-generating activities that older people can sustain from their riskfree homes may be offered. Finally, care for chronic diseases of older people should be maintained through telehealth or home care services.

must-act-to-prevent-community-spread. Accessed: 08.08.2021.

3. Holt-Lunstad J, Smith TB, Baker $M$ et al. Loneliness and social isolation as risk factors for mortality: a meta-analytic review. Perspect Psychol Sci 2015;10(2):227-37. (PMID: 25910392).

4. Lim MA, Kurniawan AA. Dreadful consequences of sarcopenia and osteoporosis due to COVID-19 containment. Geriatr Orthop Surg Rehabil 2021;12:215145932199274. (PMID: 33628613).

5. Wang P-Yu, Li Y, Wang $Q$. Sarcopenia: an underlying treatment target during the COVID-19 pandemic. 


\section{Nutrition 2021;84:111104. (PMID: 33421827)}

6. Yildirim H, Işik K, Aylaz R. The effect of anxiety levels of elderly people in quarantine on depression during covid-19 pandemic. Soc Work Public Health 2021;36(2):194-204. (PMID: 33413035). (In Turkish).

7. Pant S, Subedi M. Impact of COVID-19 on the elderly. J Patan Acad Heal Sci 2020;7(2):32-8. (DOI: https://doi.org/10.3126/jpahs. v7i2.31104).

8. Altın Z. Elderly people in COVID-19 outbreak. J Tepecik Educ Res Hosp 2020;30:49-57. (DOI:10.5222/ terh.2020.93723). (In Turkish).

9. Berg BL, Lune H. Qualitative Research Methods for Social Sciences. 8th ed. Boston, MA: Pearson Education 2012, pp 101-152. [Internet]. Available from:https://sisis.rz.htw-berlin.de/ inh2012/12424693.pdf. Accessed: 08.08.2021.

10. Pitaloka D, Hsieh E. Health as submission and social responsibilities: Embodied experiences of Javanese women with type II diabetes. Qual Health Res 2015;25(8):1155-65. (PMID: 25810467).

11. Gencer N. Being elderly in COVID-19 process: evaluations on curfew for 65-year-old and over citizens and spiritual social. TJSWR 2020;4(2):35-42. [Internet]. Available from: https://dergipark.org.tr/tushad. Accessed: 08.08.2021. (in Turkish).

12. Türk A. An evaluation on the elderly practices and the psycho-social status of the elderly during the coronavirus (Covid-19) pandemic process. Social Work 2020;2(July):36-46. Available from: http:// shuder.org/Resimler/959f9722-72d9-45f0-b560abaebce3779fsh-dergisi-temmuz-aralik-2020pdf.pdf. Accessed: 08.08.2021. (in Turkish).

13. Eiguren $A$, Idoiaga $N$, Berasategi N, Picaza M. exploring the social and emotional representations used by the elderly to deal with the COVID-19 pandemic. Front Psychol 2021;11(586560):1-11. (PMID: 33584418).

14. Meng $\mathrm{H}, \mathrm{Xu}$ Y, Dai J et al. Analyze the psychological impact of COVID-19 among the elderly population in China and make corresponding suggestions. Psychiatry Res 2020; 289:112983. (PMID: 32388175).

15. Hag Hamed $D$, Daniel M. The influence of fatalistic beliefs on health beliefs among diabetics in Khartoum, Sudan: a comparison between Coptic Christians and Sunni Muslims. Glob Health Promot 2019;26(3):15-22. (PMID: 28730875).
16. Jimenez T, Restar A, Helm PJ et al. Fatalism in the context of COVID-19: Perceiving coronavirus as a death sentence predicts reluctance to perform recommended preventive behaviors. SSM - Popul Heal 2020;11:100615. (PMID: 32572381).

17. Browne RAV, Macêdo GAD, Cabral LLP et al. Initial impact of the COVID-19 pandemic on physical activity and sedentary behavior in hypertensive older adults: an accelerometer-based analysis. Exp Gerontol 2020;(142):111121 (PMID: 33132145).

18. LiW, Yang Y, Liu ZH et al. Progression of mental health services during the COVID-19 outbreak in China. Int J Biol Sci 2020;16(10):1732-8. (PMID: 32226291).

19. Xiang $X$, Lu $X$, Halavanau $A$ et al. Modern senicide in the face of a pandemic: an examination of public discourse and sentiment about older adults and COVID-19 using machine learning. Journals Gerontol Ser B 2021;14;76(4):1-11. (PMID: 32785620).

20. Bui TTM, Button P, Picciotti EG. Early evidence on the impact of COVID-19 and the recession on older workers. NBER Work Paper No: 27448. 2020;1-21. [Internet]. Available from: http://www.nber.org/papers/w27448. Accessed: 08.08.2021.

21. Turkish Statistical Institute (TURKSTAT). Elderly Statistics, 2020. [Internet]. Available from: https:// data.tuik.gov.tr/Bulten/Index?p=Elderly-Statistics-2020-37227. 2020. Accessed: 01.07.2021. (in Turkish).

22. Arthur-Holmes F, Akaadom MKA, Agyemang-Duah W et al. Healthcare concerns of older adults during the COVID-19 outbreak in low- and middle-ıncome countries: lessons for health policy and social work. J Gerontol Soc Work 2020;63(6-7):717-23. (PMID: 32808585).

23. Burki T. The online anti-vaccine movement in the age of COVID-19. Lancet Digit Heal 2020;2(10):e504-5. (PMID: 32984795).

24. Republic of Turkey Ministry of Interior. Current situation in Turkey. Curfew circular for those aged 65 and over and those with chronic illness (21.03.2020). [Internet]. Available from: https://www.icisleri.gov.tr/. Accessed: 01.07.2021. (in Turkish).

25. Akyüz SS. The role of communication practices and political affiliations in anti-vaccine attitude and transparency perception. eJNM 2021; 5 (2), 172-185. (DOI : 10.17932/IAU.EJNM.25480200.2021/ejnm_ v5i2005). (in Turkish). 